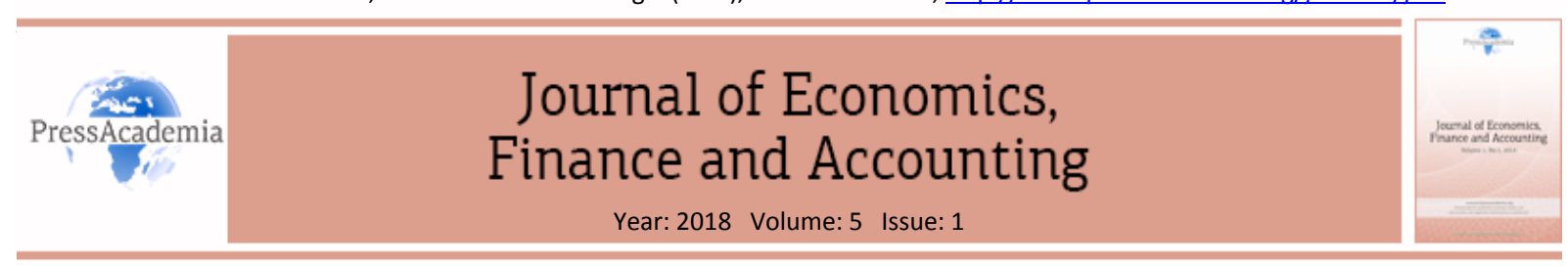

\title{
THE INFLUENCE OF CHARACTERISTICS OF THE BOARD OF COMMISSIONERS, AUDIT COMMITTEE MEETINGS AND AUDITOR TYPE ON INTELLECTUAL CAPITAL DISCLOSURE
}

\author{
DOI: 10.17261/Pressacademia.2018.819
}

JEFA- V.5-ISS.1-2018(13)-p.144-151

\author{
Eno Firmansa ${ }^{1}$, Adam Zakaria ${ }^{2}$, Marsellisa Nindito ${ }^{3}$ \\ ${ }^{1}$ State University of Jakarta, Faculty of Economics, Gedung R Kampus, Daerah Khusus Ibukota Jakarta, Indonesia. \\ eno.firmansa@gmail.com, ORCID: 0000-0002-6567-9793 \\ 2 State University of Jakarta, Faculty of Economics, Gedung R Kampus, Daerah Khusus Ibukota Jakarta, Indonesia. \\ adamzakaria@unj.ac.id, ORCID: 0000-0001-5996-5729 \\ ${ }^{3}$ State University of Jakarta, Faculty of Economics, Gedung R Kampus, Daerah Khusus Ibukota Jakarta, Indonesia. \\ lisa nindito@yahoo.com, ORCID: 0000-0003-1648-4129
}

To cite this document

Firmansa, E., Zakaria, A., Nindito, M., (2018). The influence of characteristics of the board of commissioners, audit committee meetings and auditor type on intellectual capital disclosure. Journal of Economics, Finance and Accounting (JEFA), V.5(1), p.144-151.

Permemant link to this document: $\mathrm{http}: / /$ doi.org/10.17261/Pressacademia.2018.819

Copyright: Published by PressAcademia and limited licenced re-use rights only.

\begin{abstract}
Purpose - To analyse the influence of characteristics of the board of commissioners, audit committee meetings and auditor type on the intellectual capital disclosure of service companies listed on the Indonesian Stock Exchange in 2015.

Methodology - The sample size used was 107 service-industry firms listed on the Indonesian Stock Exchange in 2015.

Findings - The frequency of the board of commissioners' meetings, the frequency of the audit committee's meetings and auditor type each have a positive and significant influence on intellectual capital disclosure. Gender diversity in the board of commissioners has a negative and significant influence on intellectual capital disclosure.

Conclusion - The Independent variables board of commissioners meeting frequency, audit committee meeting frequency and auditor type have a positive and significant influence on intellectual capital disclosure. Gender diversity in the board of commissioners has a negative and significant influence on intellectual capital disclosure.
\end{abstract}

Keywords: Board of commissioners' meeting, gender diversity, audit committee's meeting, auditor type, intellectual capital disclosure. JEL Codes: M41

\section{INTRODUCTION}

Intellectual capital is a current topic of discussion due to the fact that companies are no longer competing solely in terms of tangible assets but are also now focusing on intangible assets. Companies' advantages in terms of intellectual capital are expected to enable them to survive in the midst of dynamic competition. In Indonesia, the topic of intellectual capital began to develop following the advent of Indonesian Statement of Financial Accounting Standard/Pernyataan Standar Akuntansi Keuangan (PSAK) No. 19 revision 2000 on intangible assets (Faza and Hidayah, 2015).

The disclosure of intellectual capital remains a voluntary activity for a company, and there are no standard rules governing the components and procedures for its reporting. However, this does not mean that intellectual capital disclosure has no effect on those companies that do choose to report it, especially considering the shift in reporting towards integrated reporting, whereby the company focuses not only on financial information but is also beginning to include related information strategy, governance, performance and future prospects, thus providing some clarity in terms of the ways in which a company contributes to the (wider) society.

Research on the effects of intellectual capital disclosure itself has begun to emerge, both inside and outside the country. Widarjo (2011) found that intellectual capital disclosure has a positive effect on corporate value as it is considered able to minimise the level of information asymmetry so that investors can carefully assess and analyse a company for the foreseeable future. Similar research was conducted by Jihene and Robert (2013), who also stated that the disclosure of information related to intellectual capital has a positive influence on the formation of a company's value. 
Boujelben and Affes (2013) found that intellectual capital disclosure, especially with regard to the components of human capital and structural capital, could reduce the cost of equity capital of companies listed on the French Stock Exchange. Similarly, Prastiwi and Wulandari (2014), in their research, found that companies that reveal more information related to intellectual capital are considered to encourage greater confidence among those investors associated with the company. A company's reduced cost of capital means that it is able to reduce its stock return rate due to a reduced level of information asymmetry between management and investors.

Taliyang et al. (2014) found that the disclosure of information related to intellectual capital in the company's annual report for firms in the information technology, consumer goods, manufactured goods and financial services industries listed on the Bursa Malaysia had an influence on market capitalisation. Research with similar results has also been carried out by Abdiani and Nugrahanti (2014), finding that companies with high intellectual capital disclosure also have high market capitalisation. Prasanti and Putra (2014) found that a wider disclosure of intellectual capital reduces the amount of underpricing of newlyissued Initial Public Offerings (IPOs).

Some of the above research illustrates that intellectual capital disclosure has the ability to shape the public perception of a company. It should therefore become a reference point for companies to begin focusing on intellectual capital, since if a company has good intellectual capital, then the tendency to disclose information related to its intellectual capital will also increase. In theory, the more information a company discloses, the more positive its perception in the community, meaning that people may become convinced that companies in Indonesia also have a competitive value that is not less than foreign companies.

According to Muttakin et al. (2015), relatively little research has been conducted into the influence of the components of corporate governance implementation on intellectual capital disclosure. In Indonesia, research tracing the relationship of both has started to be developed in recent years. Studies conducted by Yuniasih et al. (2014), Rahim and Wahyudin (2015), Uzliawati (2015) and Wahyuni and Rasmini (2016), as examples, have examined the effect of the board of commissioners on intellectual capital disclosure. Other studies have also been conducted outside Indonesia; for example, Taliyang et al. (2011), Gan et al. (2013), Moeinfar et al. (2013) and Muttakin et al. (2015). Therefore, this research is a replica of research that has been carried out previously and examines the factors that encourage a company to carry out intellectual capital disclosure. Based on this, the researcher will conduct a study entitled 'The Influence of Characteristics of the Board of Commissioners, Audit Committee Meetings and Auditor Type on Intellectual Capital Disclosure'.

This research will demonstrate the impact of non-financial factors, namely the frequency of meetings of the board of commissioners, gender diversity in the board of commissioners, the frequency of audit committee meetings and auditor type on intellectual capital disclosure in service-industry companies listed on the Indonesian Stock Exchange in 2015. Board of commissioners meetings will increase the possibility of discussion regarding intellectual capital disclosure, all the while considering the risks and benefits of disclosing information about intellectual capital. A board of commissioners that has gender diversity will enable it to have a broader view, since women have different ways of thinking and tend to weigh up risks and benefits in more detail than do men. The outcomes of audit committee meetings will be taken by the board of commissioners as recommedations for the company's future; in this case, a recommendation on the level of intellectual capital information a company should disclose in its annual report. Auditor type plays a role in connecting a company with its shareholders and will maintain its image by minimising the degree of information asymmetry in such a way that enables it to advise the company to disclose information related to intellectual capital.

\section{LITERATURE REVIEW}

According to Certo et al. (2011), signalling theory has three important components. The first component is the signaller. A signaller is a party who is directly involved with a company and who knows all of the information related to the company concerned. The second component is the signal. The signal comprises the information that the signaller knows, both positive and negative. This information is special because it is known only by the signaller. The final component is the receiver; a party lacking information about a company but who wants to obtain this information (i.e. the signal). Signalling theory focuses on the communication that takes place between the signaller and receiver to reduce the occurrence of information asymmetry. Usually, such communication conveys positive information about a company so that the company becomes a positive value in the eyes of stakeholders. In order for this aim of the signalling to be achieved, the signaller will provide information that will trigger the receiver to perform a favourable action based on the information received from the signaller.

\subsection{Intellectual Capital Disclosure}

According to the OECD (2008), intellectual capital comprises non-physical resources that are used for the establishment of value in the future. Sveiby, in Unerman et al. (2007), states three categories of intellectual capital: (1) Internal (Structural) 
Capital; (2) External (Relational) Capital; and (3) Competence (Human) Capital. A company's disclosure of intellectual capital is voluntary; however, it is something that companies are increasingly required to do due to the fact that nowadays they compete in areas such as innovation, ideas and creativity. According to Siahaan (2005), the disclosure of intellectual capital by a company provides valuable information to investors that can help them to reduce the level of uncertainty pertaining to the company's future prospects and aid their evaluation of the company. Intellectual capital disclosure is thus a tool with which a company is able to communicate with stakeholders (Chariri and Pratama, 2013). According to Ismail, in Neysi et al. (2012), the content of a company's intellectual capital disclosure relates to its intangible assets and the results of its knowledge-based activity.

Intellectual capital disclosure is able to produce not only credibility for the company in the eyes of its employees and stakeholders, it can also help prevent financial loss and the spreading of rumours that can affect the company's reputation. A company will include intellectual capital disclosure in its annual report with the aim of assisting it in the areas of strategy formulation, evaluating the implementation of its strategies and assisting in withdrawal decisions related to diversification and expansion, in addition to serving as the basis of its compensation and communication to external shareholders (Marr et al. (2003), in Taliyang (2011))

\subsection{Characteristics of the Board of Commissioners}

According to Indonesian Financial Services Authority/Otoritas Jasa Keuangan (OJK) Regulation number 33 /POJK.04/2014 Chapter I Article 1 Subsection 3, the Board of Commissioners is a public company that has a duty to carry out either general supervision or supervision that is specifically related to a base calculation, as well as giving advice to management. The board of commissioners can thus affect the performance of a company through its use of strategic supervision and the degree of control it exerts over management. The board of commissioners develops a company's strategy, protects shareholders' rights and also oversees the work of its directors and the company's operational performance. The board of commisioners usually becomes visible in the event that a company faces a financial crisis.

\subsection{Meeting Frequency of the Board of Commissioners}

Meetings of the board of commissioners are held when the company wishes to take decisions related to policy. In its meetings, the board of commissioners will discuss the performance, activity and mechanisms in place within the company. The commissioners should ensure that meetings of the board as well as those of any related committees are conducted according to an agreed schedule/agenda, and members of the board of commissioners should have sufficient time to enable them to perform their duty. The board of commissioners of a company should ensure there are regulations in place with regard to its members also serving on the boards of commissioners of other companies.

OJK Regulation number 33 /POJK.04/2014 Chapter III Third Section Article 31 Subsection 1-4 states that the board of commissioners must conduct a meeting at least once every two months, at which a majority of the members must be present. The board of commissioners must also hold a meeting with management at least once every four months. Such meetings provide the opportunity for more in-depth discussion to take place in relation to the company's intellectual capital disclosure.

H1: The frequency of meetings of the board of commissioners has a postive effect on intellectual capital disclosure.

\subsection{Gender Diversity in the Board of Commissioners}

According to Indonesia Company Law (ICL) 2007 Article 108 section 5, a company whose activity is related to the accumulation or management of fuds from the society, the issuing of debt to the public, as well as the public company, should have a board of commissioners comprising at least two members. In practice, however, there is no firm regulation in Indonesia stating that a company's board of commissioners must contain any female members, or, if there are female members, how many the board should contain. However, there is a growing tendency all over the world for boards of commissioners to contain female members.

There is a tendency for boards of commissioners with a more balanced male/female ratio to more effectively identify the criteria required for strategy formulation. Females tend to obey the code of conduct and ensure that communication is good as well as focus on the non-financial measurements of performance such as employee and customer satisfaction, diversity and social responsibility.

H2: Gender diversity in the board of commissioners has a positive effect on intellectual capital disclosure.

\subsection{Meeting Frequency of the Audit Committee}

The audit committee is a committee that operates under the board of commissioners and plays an important role in the delivery of good corporate governance. The duty of the audit committee is to assist in the control function that is 
conducted by the board of commissioners. The audit committee is in charge of overseeing the integrity of the company's financial reports and qualification. It monitors the independence of the company's external auditors and the performance of both the internal audit and external auditors, in addition to preparing the company's annual report for settlement by the OJK (Indonesia's CG Manual).

As with the board of commissioners, the audit committee also meets periodically. OJK Regulation number 55 /POJK.04/2015 Chapter IV Article 13-16 states that meetings of the audit committee must be held at least once every three months. Meetings conducted by the audit committee will give impact to the board of commissioners in terms of its provision of suggestions for withdrawal decisions; thus, frequent meetings of the audit committee will indirectly increase the possibility of intellectual capital disclosure.

H3: Meeting frequency of the audit committee positively affects intellectual capital disclosure.

\subsection{Types of Auditor}

The independence of its external auditors is one of the important elements of control conducted by the company. An independent audit that is conducted by an audit office, the results of which are made available to the public, has the effect of increasing the credibility of a company as well as attracting investors (Indonesia's CG Manual). There are two kinds of Public Accounting Firms/Kantor Akuntan Publik (KAP) in Indonesia: KAPs affiliated with the Big Four (Price Waterhouse Coopers, Ernst \& Young, Delloite and KPMG), and KAPs that are not affiliated with the Big Four. The external auditor is responsible for acting as a bridge between the company and its stakeholders. The larger the size of the independent external auditing firm, the more the independent external auditor is able to protect the company's reputation. This can be seen in the quality of the audit that is conducted, whereby the independent external auditors will seek to minimise the degree of information asymmetry that occurs.

H4: The type of auditor positively affects intellectual capital disclosure.

\section{DATA AND METHODOLOGY}

\subsection{Sample and Data}

The population of this research comprised the 302 companies operating in the service sector that were registered on the Indonesian Stock Exchange in 2015. The sample of companies used was determined using the non-probability sampling method, which gave a sample size of 107 companies.

\section{Table 1: Sampling Criteria}

\begin{tabular}{|l|l|}
\hline Criteria & Number \\
\hline Service-industry companies listed on the Indonesian Stock Exchange in 2015 & 302 \\
\hline Companies that did not publish an annual report in 2015 & $(18)$ \\
\hline Companies that have zero women on their Board of Commissioners in 2015 & $(162)$ \\
\hline $\begin{array}{l}\text { Companies with no clear explanation regarding the meeting frequency of its Board of } \\
\text { Commissioners and/or Audit Committee }\end{array}$ & $(15)$ \\
\hline Sample size & 107 \\
\hline
\end{tabular}

\subsection{Research Variables}

Intellectual capital disclosure was measured using Indonesia's Intellectual Capital Disclosure developed by Ulum (2015), wherein the measurement was adjusted to the condition of the annual report in Indonesia with reference to the Decision of the Chairman of the Capital Market and Financial Institutions Supervisory Agency/Badan Pengawas Pasar Modal dan Lembaga Keuangan (BAPEPAM) and LK Number: Kep-431 / BL / 2012 concerning Submission of Issuer's Annual Report or Public Company. The items measured are as follows:

Table 2: Intellectual Capital Disclosure Measurement Items

\begin{tabular}{|c|c|c|}
\hline Internal Capital & External Capital & Human Capital \\
\hline 1. Vision and Mission & 1. Brand & 1. Number of employees \\
\hline 2. Ethics code & 2. Customer & 2. Educational level \\
\hline 3. Patent right & 3. Customer loyalty & 3. Employees' qualification \\
\hline 4. Copyright & 4. Company name & 4. Employees' knowledge \\
\hline 5. Trademarks & 5. Distribution network & 5. Employees' competence \\
\hline 6. Management philosophy & 6. Business collaboration & 6. Education and training \\
\hline
\end{tabular}




\begin{tabular}{|c|c|c|}
\hline $\begin{array}{l}\text { 7. Organisational culture } \\
\text { 8. Management process } \\
\text { 9. Information system } \\
\text { 10. Network system } \\
\text { 11. Cooperate governance } \\
\text { 12. Violation reporting system } \\
\text { 13. Comprehensive financial } \\
\text { 14. Derformance analysis } \\
\text { 15. Capital structure }\end{array}$ & $\begin{array}{ll}\text { 7. } & \text { Licence agreement } \\
\text { 8. } & \text { Profitable contracts } \\
\text { 9. } & \text { Franchise agreement } \\
\text { 10. } & \text { Acknowledgement } \\
\text { 11. } & \text { Certification } \\
\text { 12. } & \text { Marketing strategy } \\
\text { 13. } & \text { Market share }\end{array}$ & $\begin{array}{l}\text { 7. Related training types } \\
\text { 8. Employee turnover }\end{array}$ \\
\hline
\end{tabular}

The calculation of intellectual capital disclosure was carried out using the content analysis method. The company's annual report was then scored 1 (one) if the company discloses the attributes in the intellectual capital disclosure assessment scheme, and 0 (zero) if the company does not disclose the attributes of the intellectual capital disclosure (Wahyuni and Rasmini, 2016). Measurements were then made by dividing the actual number of scores achieved by the company with the supposed total number of scores.

The independent variables are the frequency of meetings of the board of commissioners as measured by the number of meetings of the board of commissioners during the observation year; gender diversity in the board of commissioners, measured by the percentage of female members in the board of commissioners; the frequency of audit committee meetings as measured by the number of board meetings during the observation year; and auditor type, measured using a dummy variable, i.e. 1 (one) for companies audited by a KAP affiliated with the Big Four and 0 (zero) for companies audited by a KAP not affiliated with the Big Four.

\subsection{Data Analysis Method}

The data collected based on observations then had to pass a series of classical assumption tests in the form of a normality test, multicollinearity test, heteroscedasticity test and autocorrelation test. Data that passed all four of these tests were then subjected to hypothesis testing. This was conducted by multiple regression analysis, using the following equation:

ICDScore $=\alpha+\beta_{1} \mathrm{BOC}_{\text {Meeting }}+\beta_{2} \mathrm{BOC}_{\text {Gender }}+\beta_{3} \mathrm{AC}_{\text {Meeting }}+\beta_{4} \mathrm{AUD}_{\text {Type }}$ (Formula 1)

ICD

$=$ Intellectual Capital Disclosure Score

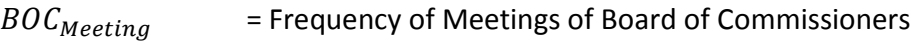

$B O C_{\text {Gender }} \quad=$ Percentage of Women as Members of Board of Commissioners

$A C_{\text {Meeting }}=$ Meeting Frequency of Audit Committee

AU $D_{\text {Type }} \quad$ Type of Auditor

$\alpha \quad=$ Constant

$\beta_{1} \ldots \beta_{n} \quad$ = Direction of regression coefficient

\section{FINDINGS AND DISCUSSION}

The classic assumption tests were carried out, with no problems to report. The value of $F$ in the model used is 15.798 , which is greater than the $\mathrm{F}$ table $(15.136>2.46)$. As for the $\mathrm{p}$-value, the value of Sig. is 0.000 , which is less than $0.05(0.000<0.05)$. This means that the model is feasible to use. The value of the Adjusted R Square in the model used for this research is 0.358. This means that the variables Frequency of Meetings of Board of Comissioners, Gender Diversity in the Board of Commissioners, Meeting Frequency of Audit Committee and Type of Auditor affect the intellectual capital disclosure by $35.8 \%$, with the remaining $64.2 \%$ influenced by other variables of value that arise from the regression model as well as the results of the hypothesis test.

The regression value of this study is as follows:

$$
\mathrm{ICD}=0.409+0.006 \mathrm{BOC}_{\mathrm{MEET}}-0.279 \mathrm{BOC}_{\mathrm{GENDER}}+0.007 \mathrm{AC}_{\mathrm{MEET}}+0.054 \mathrm{AUD}_{\mathrm{TYPE}}+\varepsilon
$$




\subsection{First Hypothesis}

A $t$ value of 2680 was obtained, and the value of $t$ was greater than the $t$ table $(2.680>1.98350)$, thereby indicating that the frequency of board meetings positively affects intellectual capital disclosure. The probability value of $t$ for board meeting frequency was 0.009 , where the probability value of $t$ is smaller than $0.05(0.009<0.05)$, thus the effect is significant. Hypothesis 1 is therefore accepted. The greater the frequency with which the board of commissioners meets during a year, the greater the level of information discosure related to intellectual capital in the company's annual report.

The board of commissioners has two main functions in relation to corporate governance, namely an advisory function, whereby it provides advice to management related to the company's strategic and operational plan; and a supervisory function, whereby it oversees the performance of the company. Both of these functions carry a responsibility, one of which is the responsibility of the board of commissioners to protect the company's reputation. Both functions can be achieved if the board of commissioners of a company is running effectively. Meetings can also be used to measure the effectiveness of a company's board of commissioners. This is because in the meeting, the board of commissioners will discuss the strategic steps that need to be taken by the company to improve the quality and value of the company in the eyes of the public; thus, the more often the board of commissioners meets, the greater the level of discussion concerning what should be disclosed to the community. This will be regarded as greater openness on the part of the company in this era of information transparency, whereby the information provided is also capable of yielding benefits for the company, one of which is the disclosure of intellectual capital.

The disclosure of intellectual capital thus becomes one of the strategic steps that a company can take to improve its reputation, which can then be discussed and decided at the board of commissioners' meeting. This refers to signalling theory, wherein intellectual capital disclosure is considered to be able to signal to investors that a company is worthy of their trust (Chariri and Pratama, 2013). The results of this study support research previously conducted by Uzliawati (2015) and Siahaan and Wahidahwati (2015).

\subsection{Second Hypothesis}

A t value of 3.425 was obtained, with the value of $t$ being greater than the $t$ table $(3.425>1.98350)$ and with a negative sign, which indicates the opposite direction; thus, gender diversity in the board of commissioners negatively affects intellectual capital disclosure. The probability value of $\mathrm{t}$ for gender diversity in the board of commissioners is 0.001 , where the probability value of $t$ is less than $0.05(0.001<0.05)$, meaning the effect is significant. That means that Hypothesis 2 is not accepted. A greater proportion of women in the composition of the board of commissioners will actually reduce the level of intellectual capital disclosure undertaken by a company. Women will instinctively consider risks more mature a greater extent than men, but men are more likely to be risk-takers than women. On the one hand, companies that disclose information related to their intellectual capital run the risk of this information becoming known to their competitors, yet, on the other hand, it can also bring benefits to the company in terms of reputation. And in an era in which companies are under pressure to provide transparency, men are more likely to make decisions about the steps a company needs to take in order to maintain its value in the eyes of the public.

Another element that supports the emergence of these results concerns aspects of the social and cultural values that are present in Indonesia. Indonesia retains a patriarchal culture, whereby men wield greater power than women. Decisions on whether or not to disclose information pertaining to intellectual capital are typically made by the president of the commissioners as part of the strategic planning process, and the majority of the commissioner positions are occupied by men. The lack of women who sit on boards of commissioners, especially those who serve as president of the board of commissioners, acts as proof of the high level of gender inequality in Indonesia.

In relation to signalling theory, a significant negative relationship between gender diversity and intellectual capital disclosure indicates that the presence of women on the board of commissioners may still not be a good signaller in terms of information related to intellectual capital. This is probably due to a lack of competence on the part of those women who do sit on boards of commissioners, particularly with regard to the understanding related to intellectual capital disclosure. The results of this study contradict the research conducted by Yuniasih et al. (2014).

\subsection{Third Hypothesis}

An arithmetic $t$ value of 2818 was obtained, with the value being greater than that shown in the t table (2.818> 1.98350), thus indicating that audit committee meeting frequency positively affects intellectual capital disclosure. The probability value of $t$ for board meeting frequency is 0.006 , where the probability $t$ value is less than $0.05(0.006<0.05)$, thus indicating that the effect is significant. This means that Hypothesis 3 is accepted. The more often the audit committee meets during the course of a year, the greater the level of intellectual capital disclosure of a company. 
The audit committee is established by the board of commissioners in order to assist it in the execution of its advisory and oversight functions. One of the oversight functions for which the audit committee is responsible is overseeing the company's financial statements and disclosures. The implementation of this responsibility thus becomes part of the agenda for the audit committee's meetings, whereby the committee reviews the financial information to be issued by the company and ensures the reliability of the company's financial statements. Matters relating to the information that will be included in the company's annual report will also be discussed as part of the audit committee's meetings. The more frequently the audit committee convenes, the greater the opportunity for its members to discuss the items to be included in the information with regard to intellectual capital, taking into consideration that today's stakeholders rely on both Financial and non-financial information. According to Karamanou and Vafeas, in Sudarno and Prameswari (2014), the greater the amount of time an audit committee spends in its meetings, the more efficient its monitoring with regard to a company's report.

In relation to signalling theory, in conducting its meetings to review the financial statements and disclosure, the audit committee ensures that the company's annual report includes not only the mandatory information that investors consider, but also includes voluntary information, since the greater a company's voluntary disclosure of information, the greater the signal sent out by the company concerning its transparency, meaning that the company increasingly has value in the eyes of the public. The results of this study are in line with those from research conducted by Uzliawati et al. (2014) and Wahyuni and Rasmini (2016), but they are contrary to the results obtained by Ghorbel and Hela (2016).

\subsection{Fourth Hypothesis}

An arithmetic $t$ value of 2,046 was obtained, with the value of arithmetic $t$ being greater than in the table (2.046>1.98350), meaning the type of auditor positively affects intellectual capital disclosure. The probability value of arithmetic $t$ for auditor type is 0.043 , which is smaller than $0.05(0.043<0.05)$, so the effect is significant. This means that Hypothesis 4 is accepted. A KAP which is affiliated with the Big 4 audit firms is allegedly able to persuade its clients to disclose more voluntary information as a measure to maintain its reputation as a large KAP affiliation, since the value of a KAP is perceived by how the users of financial statements use the information contained in audited reports. This is supported by the collateral theory which states that a KAP which is affiliated with the Big 4 will continue to maintain its position in the market by providing independent, accurate and beneficial reports on user reports since the reputation of the KAP becomes a guarantee of the quality of the audits it performs on its clients (DeAngelo in Vaicekauskas, 2014).

The quality of the audit performed by a Big 4-affiliated KAP tends to be better than that carried out by a KAP that is not affiliated with the Big 4. A KAP which is affiliated with the Big 4 has better independence and competency than a KAP which is not affiliated with the Big 4. A KAP that is affiliated with the Big 4 has more better-qualified auditors and the job rotation that is taken to maintain its independence is better than in a KAP which is unaffiliated with the Big 4 (Vaicekauskas, 2014). The competence of the auditors at a Big 4-affiliated KAP is greater due to there being more specialised and skilled auditors, better system support and greater incentives to support the achievement of quality audit results due to tighter regulation and more frequent inspections (Che et al., 2016). Due to the advantages that exist in terms of independence and the competence of the auditors working at a KAP which is affiliated with the Big 4, the company as a client also tends to consider more of the suggestions that are given by the auditor; in this case, one of the suggestions involves increasing the level of information disclosure related to the company, which will in turn encourage the company to make greater disclosures related to intellectual capital in their financial reports. The use of the services of a KAP which is affiliated with one of the Big 4 audit firms also serves to signal to the users of the financial reports that the information provided by the company is more trustworthy and reliable (Aprisa, 2016). The results of this study support research conducted by Branco et al. (2012) and Aprisa (2016), but they are contrary to the research of Al-Hamadeen and Suwaidan (2014).

Table 3: Comparative Results of the 4 Hypotheses

\begin{tabular}{|l|l|}
\hline Hypothesis & Result \\
\hline $\begin{array}{l}\text { Frequency of meetings of the board of } \\
\text { commissioners positively affects intellectual capital } \\
\text { disclosure. }\end{array}$ & $\begin{array}{l}\text { The frequency of meetings of the board of commissioners } \\
\text { positively and significantly affects intellectual capital disclosure. } \\
\text { Therefore, Hypothesis } 1 \text { is accepted. }\end{array}$ \\
\hline $\begin{array}{l}\text { Gender diversity in the board of commissioners } \\
\text { positively affects intellectual capital disclosure. }\end{array}$ & $\begin{array}{l}\text { Gender diversity in the board of commissioners negatively and } \\
\text { significantly affects intellectual capital disclosure. Therefore, } \\
\text { Hypothesis } 2 \text { is not accepted. }\end{array}$ \\
\hline $\begin{array}{l}\text { Meeting frequency of the audit committee } \\
\text { positively affects intellectual capital disclosure. }\end{array}$ & $\begin{array}{l}\text { Meeting frequency of the audit committee positively and } \\
\text { significantly affects intellectual capital disclosure. Therefore, } \\
\text { Hypothesis 3 is accepted. }\end{array}$ \\
\hline $\begin{array}{l}\text { Auditor type positively affects intellectual capital } \\
\text { disclosure. }\end{array}$ & $\begin{array}{l}\text { Auditor type positively and significantly affects intellectual capital } \\
\text { disclosure. Therefore, Hypothesis 4 is accepted. }\end{array}$ \\
\hline
\end{tabular}




\section{CONCLUSION}

The results of this study indicate that of the four independent variables studied, the variables frequency of board of commissioners meeting, audit committee meeting frequency and auditor type have a positive and significant influence on intellectual capital disclosure. Gender diversity in the board of commissioners, however, has a negative and significant influence on intellectual capital disclosure.

This study has some limitations, including the use of non-financial independent variables only, research objects that cover only the service sector and the fact that the period of the study covers only the year 2015. It is thus suggested that subsequent research adds other independent variables such as ownership type or industry type in addition to financial variables such as firm size or leverage. It is also suggested that other sectors are included, such as the manufacturing sector or main sector, and also that the period of years of the research is extended.

\section{REFERENCES}

Chariri, Anis, and Pratama, A. (2013). Gestalt Accounting: Corporate Commitment in Intellectual Capital Disclosure. Diponegoro University Journal of Accounting, vol. 2 no. 1, pp. 1-15.

Faza, Fardin, M. And Hidayah, E. (2014). The Influence of Intellectual Capital on Profitability, Productivity, And Corporate Value in Banking Companies Listed In Indonesia Stock Exchange (BEI). Journal of Economics and Islamic Business (EKBISI), vol. 8 no. 2, pp. $186-199$.

Muttakin, M., Khan, A., Belal, A. (2015). Intellectual Capital Disclosure and Corporate Governance: An Empirical Examination. Advances in Accounting, Incorporating Advances in International Accounting, vol. 31 no. 2, pp. 219-227.

Neysi, S., Mazraeh, S., Mousafi, Z. (2012). The Importance of Intellectual Capital Disclosure. International Journal of Business and Social Science, vol. 3 no. 15 , pp. 307-310.

Rahim, A., Atan, R. and Kamaluddin, A. (2011). Intellectual Capital Reporting in Malaysian Technology Industry. Asian Journal of Accounting and Governance, vol. 2, pp. 51-59.

Siahaan, Sisca and Wahidahwati. (2015). The Influence of Good Corporate Governance to Intellectual Capital Disclosure As a Strategy Facing the AEC. Journal of Accounting Science and Research, vol. 4 no. 12, pp. 1-18.

Sudarno and Prameswari, F. (2014). Influence of Characteristics of Audit Committee and External Auditor on Intellectual Capital Disclosure. Diponegoro University Journal of Accounting, vol. 3 no. 3, pp. 1-8.

Taliyang, S., Latif, R. and Mustafa, N. (2011). The Determinants of Intellectual Capital Disclosure among Malaysian Listed Companies. International Journal of Management and Marketing Research, vol. 4 no. 3, pp. 25-33.

Ulum, I. (2015). Intellectual Capital Disclosure: Analysis using Four Way Numerical Coding System. JAAI, vol. 19 no. 1, pp. $39-50$.

Unerman, J., Guthrie, J. and Striukova, L. (2007). UK Reporting of Intellectual Capital. Centre for Business Performance of the Institute of Chartered Accountants in England and Wales, pp. 1-72.

Uzliawati, L., Suhardjanto, D. and Djati, K. (2014). The Characteristic of Audit Committee and Intellectual Capital Disclosure in Indonesia

Banking Industry. GSTF Journal on Business Review, vol. 3 no. 2, pp. 18-24

Uzliawati, L. (2015). Board of Commissioners and Intellectual Capital Disclosure on Banking in Indonesia. Journal of Finance and Banking, vol. 19 no. 2 , pp. 226-234.

Wahyuni, M. And Rasmini, N. (2016). Influence of Corporate Governance Mechanism on Intellectual Capital Disclosure. Journal of Economic Study Bulletins, vol. 21 no. 1, pp. 48-59.

Rasmini, N., Wirakusuma, M., Yuniasih, N. (2014). The Effect of Board Diversity on the Extent of Intellectual Capital Disclosure : Empirical Study in Indonesia Stock Exchange. Asia Pacific Journal of Accounting and Finance, vol. 3 no. 1, pp. 45-58. 